\title{
Biomass Feedstock Availability in the United States: 1999 State Level Analysis
}

Marie E. Walsh ${ }^{a}$, Robert L. Perlack ${ }^{a}$, Anthony Turhollow ${ }^{a}$, Daniel de la Torre Ugarte ${ }^{b}$, Denny A. Becker ${ }^{c}$, Robin L. Graham $^{\mathrm{a}}$, Stephen E. Slinsky ${ }^{\mathbf{b}}$, and Daryll E. Ray ${ }^{\mathbf{b}}$

${ }^{a}$ Oak Ridge National Laboratory, Oak Ridge, TN 37831-6205

${ }^{b}$ University of Tennessee, Knoxville, TN 37901-1071

${ }^{\mathrm{c}}$ Science Applications International Corporation, Oak Ridge, TN 37830

April 30, 1999, Updated January, 2000

\section{Introduction}

Interest in using biomass feedstocks to produce power, liquid fuels, and chemicals in the U.S. is increasing. Central to determining the potential for these industries to develop is an understanding of the location, quantities, and prices of biomass resources. This paper describes the methodology used to estimate biomass quantities and prices for each state in the continental U.S. An Excel ${ }^{\mathrm{TM}}$ spreadsheet contains estimates of biomass quantities potentially available in five categories: mill wastes, urban wastes, forest residues, agricultural residues and energy crops. Availabilities are sorted by anticipated delivered price. A presentation that explains how this information was used to support the goal of increasing biobased products and bioenergy 3 times by 2010 expressed in Executive Order 1.3134 of August 12, 1999 is also available.

\section{Biomass Feedstock Availability}

For the purpose of this analysis, biomass feedstocks are classified into five general categories: forest residues, mill residues, agricultural residues, urban wood wastes, and dedicated energy crops. Forestry is a major industry in the United States encompassing nearly 559 million acres in publicly and privately held forest lands in the continental U.S. (USDA, 1997). Nearly 16 million cubic feet of roundwood are harvested and processed annually to produce sawlogs, paper, veneers, composites and other fiber products (USDA, 1998a). The extensive forest acreage and roundwood harvest generate logging residues and provide the potential to harvest non-merchantable wood for energy. Processing of the wood into fiber products creates substantial quantities of mill residues that could potentially be used for energy. Agriculture is another major industry in the United States. Approximately 337 million acres of cropland are currently in agricultural production (USDA, 1997). Following the harvest of many of the traditional agricultural crops, residues (crop stalks) are left in the field. A portion of these residues could potentially be collected and used for energy. Alternatively, crop acres could be used to grow dedicated energy crops. A final category of biomass feedstocks includes urban wood wastes. These wastes include yard trimmings and other wood materials that are generally disposed of in municipal solid waste (MSW) and construction/demolition (C/D) landfills. Following is a description of the potential availability of these biomass feedstocks in the United States.

\section{A. Forest Residues}

Forest wood residues can be grouped into the following categories--logging residues; rough, rotten, and salvable dead wood; excess saplings; and small pole trees $\stackrel{(1)}{ }$. The forest wood residue supplies that could potentially be available for energy use in the U.S. are estimated using an updated version of a model originally developed by McQuillan et al. (1984). The McQuillan model estimates the total quantities of forest wood residues that can be recovered by first classifying the total forest inventory by the above wood categories (for both softwood and hardwood), and by volume, haul distances, and equipment operability constraints. This total inventory is then revised downward to reflect the quantities that can be recovered in each class due to constraints on equipment retrieval efficiencies, road access to a site, and impact of site 

slope on harvest equipment choice ${ }^{-2)}$.

The costs of obtaining the recoverable forest wood residues are estimated for each category. Prices include collection, harvesting, chipping, loading, hauling, and unloading costs, a stumpage fee, and a return for profit and risk. Prices are in 1995 dollars. For the purposes of this analysis, we have included only logging residues and rough, rotten, and salvable dead wood quantities. The potential annual forest waste residues available by state for three price scenarios are presented in Table 1. Quantities are cumulative quantities at each price (i.e., quantities at $\$ 50 / \mathrm{dt}$ include all quantities available at $\$ 40 / \mathrm{dt}$ plus quantities available between $\$ 40$ and $\$ 50 / \mathrm{dt}$ ).

Polewood, which represent the growing stock of merchantable trees, has not been included in the analysis due to the fact that it could potentially be left to grow and used for higher value fiber products. It is doubtful that these trees will be harvested for energy use. However, if harvested, they could add another 17 million dry tons at less than $\$ 30 / \mathrm{dt}$ delivered; 37.7 million dry tons at less than $\$ 40$ delivered; and 65 million dry tons at less than $\$ 50 /$ dt delivered. For a more detailed explanation of the methodology used to estimate the forest wood residue quantities and prices, see Walsh et al, 1998.

Table 1: Estimated Annual Cumulative Forest Residues Quantities (dry tons), by Delivered Price and State

\begin{tabular}{|c|c|c|c|}
\hline & $<\$ 30 /$ dry ton delivered & $<\$ 40 /$ dry ton delivered & $<\$ 50 /$ dry ton delivered \\
\hline Alabama & 1009000 & 1475000 & 1899000 \\
\hline Arizona & 134000 & 200000 & 261400 \\
\hline Arkansas & 928000 & 1352000 & 1737800 \\
\hline California & 1231000 & 1819000 & 2364400 \\
\hline Colorado & 373000 & 554000 & 720300 \\
\hline Connecticut & 109000 & 159000 & 204100 \\
\hline Delaware & 26000 & 37000 & 48400 \\
\hline Florida & 515000 & 755000 & 9757000 \\
\hline Georgia & 1041000 & 1525000 & 1967800 \\
\hline Idaho ......... & 605000 & 902000 & 1179500 \\
\hline Illinois & 228000 & 330000 & 423300 \\
\hline Indiana & 253000 & 367000 & 470100 \\
\hline Iowa & 72000 & 105000 & 135000 \\
\hline Kansas & 47000 & 68000 & 88100 \\
\hline Kentucky & 475000 & 690000 & 883500 \\
\hline Louisiana & 872000 & 1275000 & 1641800 \\
\hline Maine & 806000 & 1182000 & 1529100 \\
\hline Maryland & 189000 & 273000 & 351200 \\
\hline Massachusetts & 196000 & 284000 & 366200 \\
\hline Michigan & 710000 & 1034000 & 1327900 \\
\hline Minnesota & 468000 & 682000 & 874900 \\
\hline Mississippi & 946000 & 1380000 & 1774600 \\
\hline ' & & $\longdiv { 1 }$ & \\
\hline
\end{tabular}


. Biomass Feedstock Availability in the United States: 1999 State Level Analysis

\begin{tabular}{|c|c|c|c|}
\hline Missouri & 505000 & 733000 & 938700 \\
\hline Montana & 676000 & 1007000 & 1316700 \\
\hline Nebraska & 19000 & 27000 & 34400 \\
\hline Nevada & 8000 & 11000 & 14400 \\
\hline New Hampshire & 299000 & 438000 & 564400 \\
\hline New Jersey & 70000 & 102000 & 130700 \\
\hline New Mexico & 125000 & 185000 & 241900 \\
\hline New York & 933000 & 1360000 & 1746400 \\
\hline North Carolina & 1068000 & 1557000 & 2004900 \\
\hline North Dakota & 11000 & 17000 & 21700 \\
\hline Ohio & 232000 & 335000 & 430100 \\
\hline Oklahoma & 156000 & 228000 & 292200 \\
\hline Oregon & 1299000 & 1928000 & 2515900 \\
\hline Pennsylvania & 948000 & 1377000 & 1763000 \\
\hline Rhode Island & 20000 & 27000 & 35900 \\
\hline South Carolina & 613000 & 898000 & 1158400 \\
\hline South Dakota & 33000 & 49000 & 64300 \\
\hline Tennessee & 930000 & 1351000 & 1732600 \\
\hline Texas & 557000 & 814000 & 1050700 \\
\hline Utah & 90000 & 133000 & 173000 \\
\hline Vermont & 265000 & 386000 & 497200 \\
\hline Virginia & 959000 & 1397000 & 1793600 \\
\hline Washington & 1230000 & 1825000 & 2379600 \\
\hline West Virginia & 727000 & 1056000 & 1352500 \\
\hline Wisconsin & 609000 & 886000 & 1138400 \\
\hline Wyoming & 132000 & 196000 & 256100 \\
\hline U.S. Total & 23747000 & 34771000 & 44871800 \\
\hline
\end{tabular}

\section{B. Primary Mill Residues}

The quantities of mill residues generated at primary wood mills (i.e., mills producing lumber, pulp, veneers, other composite wood fiber materials) in the U.S. are obtained from the data compiled by the USDA Forest Service for the 1997 Resource Policy Act (RPA) Assessment (USDA, 1998a). Mill residues are classified by type and include bark; coarse residues (chunks and slabs); and fine residues (shavings and sawdust). Data is available for quantities of residues generated by residue type and on uses of residues by residue type and use category (i.e., not used, fuel, pulp, composite wood materials, etc.). Data is available at the county, state, subregion, and regional level. In cases where a county has fewer than three mills, data from multiple counties are combined to maintain the confidentiality of the data provided by 
- Biomass Feedstock Availability in the United States: 1999 State Level Analysis individual mills. Data represent short run average quantities.

Because primary mill residues are clean, concentrated at one source, and relatively homogeneous; nearly 98 percent of all residues generated in the United States are currently used as fuel or to produce other fiber products. Of the 24.2 million dry tons of bark produced in the U.S., 2.2 percent is not used while 79.4 percent is used for fuel and 18 percent is used for such things as mulch, bedding, and charcoal. Only about 1.4 percent of the 38.7 million dry tons of coarse residues are not used. The remainder are used to produce pulp or composite wood products such as particle board, wafer board, and oriented strand board ( 78 percent) and about 13 percent are used for fuel. Of the 27.5 million dry tons of fine wood residues, approximately 55.6 percent are used for fuel, 23 percent are used to produce pulp or composite wood products, 18.7 percent are used for bedding, mulch and other such uses, and about 2.6 percent are unused.

The residues, while currently used, could potentially be available for energy use if utilities could pay a higher price for the residues than their value in their current uses. Data regarding the value of these residues in their current uses are difficult to obtain. Much of the residues used for fuel are used on site by the residue generator in low efficiency boiler systems to produce heat and steam. Conversations with those in the industry and other anecdotal evidence suggests that these residues could be purchased for $\$ 15-25 /$ dry ton for use in higher efficiency fuel systems. Similar anecdotal evidence suggests that residues used to produce fiber products (pulp, composite wood materials) sell for about $\$ 30-40 /$ dry ton. For the purposes of this analysis, we assume that the residues not currently used could potentially be available for energy uses at delivered prices of less than $\$ 20 /$ dry ton (assuming transportation distances of less than 50 miles). For similar transportation distances, we assume that residues currently used for fuel could be available at less than $\$ 30 /$ dry ton delivered and residues currently used for pulp, composite wood materials, mulch, bedding, and other such uses could potentially be available at delivered prices of less than $\$ 50 /$ dry ton. Table 2 presents the cumulative annual quantities of mill residues by delivered price for each state.

Table 2: Estimated Annual Cumulative Mill Residue Quantities (dry tons), by Delivered Price and State

\begin{tabular}{|c|c|c|c|}
\hline & $<\$ 20 /$ dry ton delivered & $<\$ 30 /$ dry ton delivered & $<\$ 50 /$ dry ton delivered \\
\hline Alabama & 17000 & 4581000 & 7802000 \\
\hline Arizona & 0 & 75000 & 251000 \\
\hline Arkansas & 2000 & 2497000 & 4705000 \\
\hline California & 8000 & 2294000 & 4823000 \\
\hline Colorado & 86000 & 121000 & 180000 \\
\hline Connecticut & 0 & 40000 & 91000 \\
\hline Delaware & 0 & 4000 & 16000 \\
\hline Florida & 4000 & 1412000 & 2678000 \\
\hline Georgia & 72000 & 3913000 & 7969000 \\
\hline Idaho & 69000 & 1629000 & 4400000 \\
\hline Illinois & 19000 & 117000 & 282000 \\
\hline Indiana & 31000 & 213000 & 699000 \\
\hline Iowa & 2000 & 46000 & 158000 \\
\hline Kansas & 1000 & 9000 & 20000 \\
\hline Kentucky & 109000 & 421000 & 1940000 \\
\hline Louisiana & 64000 & 1943000 & 3245000 \\
\hline Maine & 43000 & 209000 & 504000 \\
\hline
\end{tabular}


- Biomass Feedstock Availability in the United States: 1999 State Level Analysis

\begin{tabular}{|c|c|c|c|}
\hline Maryland & 0 & 13000 & 166000 \\
\hline Massachusetts & 0 & 44000 & 135000 \\
\hline Michigan & 10000 & 932000 & 1564000 \\
\hline Minnesota & 71000 & 916000 & 1121000 \\
\hline Mississippi & 128000 & 3178000 & 6029000 \\
\hline Missouri & 162000 & 315000 & 1196000 \\
\hline Montana & 17000 & 659000 & 2173000 \\
\hline Nebraska & 12000 & 21000 & 69000 \\
\hline Nevada & 0 & 0 & 0 \\
\hline New Hampshire & 23000 & 439000 & 1109000 \\
\hline New Jersey & 0 & 8000 & 21000 \\
\hline New Mexico & 25000 & 61000 & 125000 \\
\hline New York & 28000 & 495000 & 1274000 \\
\hline North Carolina & 33000 & 2060000 & 5028000 \\
\hline North Dakota & 0 & 3000 & 4000 \\
\hline Ohio & 0 & 0 & 0 \\
\hline Oklahoma & 0 & 318000 & 698000 \\
\hline Oregon & 10000 & 1738000 & 6834000 \\
\hline Pennsylvania & 172000 & 591000 & 1.628000 \\
\hline Rhode Island & 0 & 11000 & 25000 \\
\hline South Carolina & 4000 & 1706000 & 3382000 \\
\hline South Dakota & 8000 & 46000 & 124000 \\
\hline Tennessee & 202000 & 1325000 & 2018000 \\
\hline Texas & 18000 & 1649000 & 4043000 \\
\hline Utah & 20000 & 67000 & 102000 \\
\hline Vermont & 0 & 59000 & 124000 \\
\hline Virginia & 80000 & 1234000 & 2860000 \\
\hline Washington & 5000 & 2262000 & 5689000 \\
\hline West Virginia & 136000 & 459000 & 967000 \\
\hline Wisconsin & 42000 & 1202000 & 192000 \\
\hline Wyoming & 47000 & 124000 & 255000 \\
\hline U.S. Total & 1780000 & 41459000 & 90418000 \\
\hline
\end{tabular}

\section{Agricultural Residues}

http://bioenergy.ornl.gov/resourcedata/index.html 
Agriculture is a major activity in the United States. Among the most important crops in terms of average total acres planted from 1995 to 1997 are corn (77 million acres), wheat (72 million acres), soybeans ( 65 million acres), hay (60.5 million acres), cotton ( 15 million acres), grain sorghum ( 10 million acres), barley ( 7 million acres), oats ( 5 million acres), rice ( 3 million acres), and rye (1.5 million acres) (USDA, 1998b). After harvest, a portion of the stalks could potentially be collected for energy use. The analysis in this paper is limited to corn stover and wheat straw. Large acreage is dedicated to soybean production, but in general, residue production is relatively small and tends to deteriorate rapidly in the field, limiting the usefulness of soybean as an energy feedstock. However, additional residue quantities could be available from this source that have not been included in this analysis. Similarly, additional residue quantities could be available if barley, oats, rice, and rye production were included. Production of some of these crops (rice in particular) tends to be concentrated in a relatively small geographic area, and thus these crops could be an important local source of resources. Another potential source in the southern U.S. is cotton. A recent study (NEOS, 1998) suggests that approximately 500,000 dry tons of cotton gin trash is currently produced in the United States and this material is generally given away to farmers for use as a soil amendment. Another 171,000 dry tons of textile mill residues are produced, but much of this material is used to make other textiles and sells for prices in excess of $\$ 100 /$ dry ton. These quantities are not included in this analysis.

The quantities of corn stover and wheat straw residues that can be available in each state are estimated by first calculating the total quantities of residues produced and then calculating the total quantities that can be collected after taking into consideration quantities that must be left to maintain soil quality (i.e., maintain organic matter and prevent erosion). Residue quantities generated are estimated using grain yields, total grain production, and a ratio of residue quantity to grain yield,,$(3)$

The net quantities of residue per acre that are available for collection are estimated by subtracting from the total residue quantity generated, the quantities of residues that must remain to maintain quality (Lightle, 1997). Quantities that must remain differ by crop type, soil type, typical weather conditions, and the tillage system used. A state average was used for this analysis. In general, about 30 to 40 percent of the residues can be collected.

The estimated prices of corn stover and wheat straw include the cost of collecting the residues, the premium paid to farmers to encourage participation, and transportation costs.

The cost of collecting the agricultural residues are estimated using an engineering approach. For each harvest operation, an equipment complement is defined. Using typical engineering specifications, the time per acre required to complete each operation and the cost per hour of using each piece of equipment is calculated (ASAE, 1995; NADA, 1995; USDA, 1996; Doanes, 1995). For corn stover, the analysis assumes $1 \mathrm{x}$ mow, $1 \mathrm{x}$ rake, $1 \mathrm{x}$ bale with a large round baler, and pickup, transport, and unloading of the bales at the side of the field where they are stored until transport to the user facility. The same operations are assumed for wheat straw minus the mowing. The operations assumed are conservative-mowing is often eliminated and the raking operation is also eliminated in some circumstances. The method used to estimate collection costs is consistent with that used by USDA to estimate the costs of producing agricultural crops (USDA, 1996).

An additional cost of $\$ 20$ /dry ton is added to account for the premium paid to farmers and the transportation cost from the site of production to the user facility. Currently, several companies purchase corn stover and/or wheat straw to produce bedding, insulating materials, particle board, paper, and chemicals (Gogerty, 1996). These firms typically pay $\$ 10$ to $\$ 15 /$ dry ton to farmers to compensate for any lost nutrient or environmental benefits that result from harvesting residues. The premium paid to farmers depends, in part, on transportation distance with farmers whose fields are at greater distances from the user facility receiving lower premiums. Studies have estimated that the cost of transporting giant round bales of switchgrass are $\$ 5$ to $\$ 10$ per dry ton for haul distances of less than 50 miles (Bhat et al, 1992; Graham et al, 1996; Noon et al, 1996). Agricultural residue bales are of similar size, weight, and density as switchgrass bales, and a similar transportation cost is assumed. This cost is similar to the reported transportation costs of facilities that utilize agricultural residues (Schechinger, 1997). Prices are in 1995\$. For a more detailed explanation of the methodology used to estimate agricultural residue quantities and prices, see Walsh et al, 1998. The estimated annual cumulated agricultural residues quantities, by delivered price and state are contained in Table 3 . Table 3 also contains by state, the percent of the total available residues that are corn stover.

Table 3: Estimated Annual Cumulative Agricultural Residue Quantities (dry tons), by 
- Biomass Feedstock Availability in the United States: 1999 State Level Analysis

Delivered Price and State

\begin{tabular}{|c|c|c|c|c|c|c|}
\hline & \multicolumn{2}{|c|}{$\begin{array}{l}<\$ 30 / \text { dry ton } \\
\text { delivered }\end{array}$} & \multicolumn{2}{|c|}{$<\$ 40 /$ dry ton delivered } & \multicolumn{2}{|c|}{$<\$ 50 /$ dry ton delivered } \\
\hline & Quantity & $\%$ Corn & Quantity & $\%$ Corn & Quantity & $\%$ Corn \\
\hline Alabama & 0 & 0 & 0 & 0 & 19267 & 0 \\
\hline Arizona & 0 & 0 & 221864 & 24 & 221864 & 24 \\
\hline Arkansas & 0 & 0 & 859361 & 0 & 984495 & 13 \\
\hline California & 0 & $\mid 0$ & 1478283 & 40 & 1478283 & 40 \\
\hline Colorado & 0 & $\| 0$ & 2523820 & 90 & 2523820 & 90 \\
\hline Connecticut & 0 & $\|$ & 0 & 0 & 0 & 0 \\
\hline Delaware & 0 & 0 & 88077 & 0 & 300736 & 0 \\
\hline Florida & 0 & 0 & 14824 & 0 & 14824 & 0 \\
\hline Georgia & 0 & $\mid 0$ & 344423 & 0 & 779871 & 56 \\
\hline Idaho & 0 & $\mid 0$ & 1248120 & 10 & 1248120 & 10 \\
\hline Illinois & 0 & 0 & 24270757 & 94 & 24270757 & 94 \\
\hline Indiana & 0 & 0 & 11883845 & 94 & 11883845 & 94 \\
\hline Iowa & 0 & 0 & 23911214 & 99 & 2391.1214 & 99 \\
\hline Kansas & 0 & $\| 0$ & 8570003 & 48 & 8570003 & 48 \\
\hline Kentucky & 0 & $\mid 0$ & 471819 & 0 & 2280603 & 49 \\
\hline Louisiana & 0 & $\|$ & 80930 & 0 & 380557 & 79 \\
\hline Maine & 0 & $\mid 0$ & 0 & 0 & 0. & 0 \\
\hline Maryland & 0 & $\| 0$ & 272468 & 0 & 802298 & 66 \\
\hline Massachusetts & 0 & $\mid 0$ & 0 & 0 & 0 & 6 \\
\hline Michigan & 0 & 0 & 680783 & 0 & 4265671 & 84 \\
\hline Minnesota & 0 & $\| 0$ & 11935896 & 88 & 11935896 & 88 \\
\hline Mississippi & 0 & $\mid 0$ & 0 & 0 & 37877 & 0 \\
\hline Missouri & 0 & $\| 0$ & 1204353 & 0 & 4081358 & 70 \\
\hline Montana & 0 & 0 & 406592 & 9 & 406592 & 9 \\
\hline Nebraska & 0 & $\mid 0$ & 16326915 & 98 & 16326915 & 98 \\
\hline Nevada & 0 & $\mid 0$ & 15350 & 0 & $\mid 15350$ & 0 \\
\hline New Hampshire & 0 & 0 & 0 & 0 & 0 & 0 \\
\hline New Jersey & 0 & 0 & 32723 & 0 & 32723 & 0 \\
\hline New Mexico & 0 & $\| 0$ & 476529 & 55 & 476529 & 55 \\
\hline New York & 0 & $\mid 0$ & 129515 & 0 & 129515 & 0 \\
\hline North Carolina & 0 & $\| 0$ & $\mid 473229$ & 0 & 1130744 & 58 \\
\hline
\end{tabular}


- Biomass Feedstock Availability in the United States: 1999 State Level Analysis

\begin{tabular}{|c|c|c|c|c|c|c|}
\hline North Dakota & 0 & 0 & $\mid 14015$ & 0 & 3715404 & 0 \\
\hline Ohio & 0 & 0 & 7634476 & 82 & 7634476 & 82 \\
\hline Oklahoma & 3214403 & 0 & 3440745 & 7 & 3440745 & 7 \\
\hline Oregon & 0 & 0 & 155855 & 40 & 155855 & 40 \\
\hline Pennsylvania & 0 & 0 & 197689 & 0 & 1031195 & 0 \\
\hline Rhode Island & 0 & 0 & 0 & 0 & 0 & 0 \\
\hline South Carolina & 0 & 0 & 239680 & 0 & 239680 & 0 \\
\hline South Dakota & 0 & 0 & 3686246 & 71 & 2852740 & 71 \\
\hline Tennessee & 0. & 0 & 300849 & 0 & 1004781 & 70 \\
\hline Texas & 0 & 0 & 4497784 & 66 & 4497784 & 66 \\
\hline Utah & 0 & 0 & 216546 & 29 & 216546 & 29 \\
\hline Vermont & 0 & 0 & 0 & 0 & 0 & 0 \\
\hline Virginia & 0 & 0 & 297986 & 0 & 585717 & 21 \\
\hline Washington & 0 & 0 & 1364254 & 30 & 1364254 & 30 \\
\hline West Virginia & 0 & 0 & 12008 & 0 & 51295 & 77 \\
\hline Wisconsin & 0 & 0 & 5179618 & 97 & 5179618 & 97 \\
\hline Wyoming & 0 & 0 & 171585 & 51 & 171585 & 51 \\
\hline U.S. Total & 3214403 & 0 & 135331029 & 81 & 150651402 & 80 \\
\hline
\end{tabular}

\section{Dedicated Energy Crops}

Dedicated energy crops include short rotation woody crops (SRWC) such as hybrid poplar and hybrid willow, and herbaceous crops such as switchgrass (SG). Currently, dedicated energy crops are not produced in the United States, but could be if they could be sold at a price that ensures the producer a profit at least as high as could be earned using the land for alternative uses such as producing traditional agricultural crops. The POLYSYS model is used to estimate the quantities of energy crops that could potentially be produced at various energy crop prices. POLYSYS is an agricultural sector model that includes all major agricultural crops (wheat, corn, soybeans, cotton, rice, grain sorghum, barley, oats, alfalfa, other hay crops); a livestock sector; and food, feed, industrial, and export demand functions. POLYSYS was developed and is maintained by the Agricultural Policy Analysis Center at the University of Tennessee and is used by the USDA Economic Research Service to conduct economic and policy analysis. Under a joint project between USDA and DOE, POLYSYS is being modified to include dedicated energy crops. A workshop consisting of USDA and DOE experts was held in November, 1997 to review the energy crop data being incorporated into the POLYSYS model.

The analysis includes cropland acres that are presently planted to traditional crops, idled, in pasture, or are in the Conservation Reserve Program. Energy crop production is limited to areas climatically suited for their production--states in the Rocky Mountain region and the Western Plains region are excluded. Because the CRP is an environmental program, two management scenarios have been evaluated--one to optimize for biomass yield and one to provide for high wildlife divesity. Energy crop yields vary within and between states, and are based on field trial data and expert opinion. Energy crop production costs are estimated using the same approach that is used by USDA to estimate the cost of producing conventional crops (USDA, 1996). Recommended management practices (planting density, fertilizer and chemical applications, rotation lengths) are assumed. Additionally, switchgrass stands are assumed to remain in production for 10 years before replanting, are harvested annually, and are delivered as large round bales. Hybrid poplars are planted at a $8 \times 10$ foot spacing ( 545 trees/acre) and are harvested in the 10 th year of production in the northern U.S., 
- Biomass Feedstock Availability in the United States: 1999 State Level Analysis

after 8 years of production in the southern U.S., and after 6 years of production in the Pacific Northwest. Poplar harvest is by custom operation and the product is delivered as whole tree wood chips. Hybrid willow varieties are suitable for production in the northern U.S. The analysis assumes 6200 trees/acre, with first harvest in year 4 and subsequent harvests every three years for a total of 7 harvests before replanting is necessary. Willow is delivered as whole tree chips.

The estimated quantities of energy crops are those that could potentially be produced at a profit at least as great as could be earned producing traditional crops on the same acres, given the assumed energy crop yield and production costs, and the 1999 USDA baseline production costs, yields, and traditional crop prices (USDA, 1999b). In the U.S., switchgrass production dominates hybrid poplar and willow production at the equivalent (on an MBTU basis) market prices. The POLYSYS model estimates the farmgate price; an average transportation cost of $\$ 8 / \mathrm{dt}$ is added to determine the delivered price. Prices are in $\$ 1997$. Table 4 presents the estimated annual cumulative quantities of energy crops by state by delivered price. For a more detailed explanation of the methodology used to estimate dedicated energy crop prices and quantities, see Walsh et al, 1998 and de la Torre Ugarte et al, 1999.

Table 4: Estimated Annual Cumulative Energy Crop Quantities (dry tons), by Delivered Price and State

\begin{tabular}{|c|c|c|c|}
\hline & $<\$ 30 /$ dry ton delivered & $<\$ 40 /$ dry ton delivered & $<\$ 50 /$ dry ton delivered \\
\hline Alabama & 0 & 3283747 & 6588812 \\
\hline Arizona & 0 & 0 & 0 \\
\hline Arkansas & 0 & 1709915 & 5509780 \\
\hline California & 0 & 0 & 0 \\
\hline Colorado & 0 & 0 & 0 \\
\hline Connecticut & 0 & 0 & 199646 \\
\hline Delaware & 0 & 0 & 31454 \\
\hline Florida & 0 & 0 & 1268290 \\
\hline Georgia & 0 & 1321438 & 3958181 \\
\hline Idaho & 0 & 0 & 0 \\
\hline Illinois & 0 & 1427349 & 7689694 \\
\hline Indiana & 0 & 418042 & 5026234 \\
\hline Iowa & 0 & 234292 & 8295486 \\
\hline Kansas & 0 & 2859261 & 11438271 \\
\hline Kentucky & 0 & 3598827 & 5128780 \\
\hline Louisiana & 0 & 3923954 & 5813200 \\
\hline Maine & 0 & 0 & 0 \\
\hline Maryland & 0 & 0 & 298653 \\
\hline Massachusetts & 0 & 0 & 235908 \\
\hline Michigan & 0 & 1154228 & 4179308 \\
\hline Minnesota & 0 & 427467 & 5783002 \\
\hline Mississippi & 0 & 5330671 & 9304782 \\
\hline Missouri & 0 & 5251442 & 12780923 \\
\hline
\end{tabular}


- Biomass Feedstock Availability in the United States: 1999 State Level Analysis

\begin{tabular}{|c|c|c|c|}
\hline Montana & 0 & 0 & 2778386 \\
\hline Nebraska & 0 & 1922058 & 5172860 \\
\hline Nevada & 0 & 0 & 0 \\
\hline New Hampshire & 0 & 0 & 158757 \\
\hline New Jersey & 0 & 0 & 142902 \\
\hline New Mexico & 0 & 0 & 0 \\
\hline New York & 0 & 0 & 3388035 \\
\hline North Carolina & 0 & 639228 & 1632077 \\
\hline North Dakota & 0 & 1928463 & 16757889 \\
\hline Ohio & 0 & 3808089 & 9657080 \\
\hline Oklahoma & 0 & 3644173 & 8083722 \\
\hline Oregon & 0 & 0 & 0 \\
\hline Pennsylvania & 0 & 0 & 2338243 \\
\hline Rhode Island & 0 & 0 & 4943 \\
\hline South Carolina & 0 & 1338745 & 2438152 \\
\hline South Dakota & 0 & 5613863 & 12757734 \\
\hline Tennessee & 0 & 6616717 & 9350856 \\
\hline Texas & 0 & 4549899 & 9139885 \\
\hline Utah & 0 & 0 & 0 \\
\hline Vermont & 0 & 0 & 333465 \\
\hline Virginia & 0 & 1260668 & 2609867 \\
\hline Washington & 0 & 0 & 0 \\
\hline West Virginia & 0 & 269250 & 1190299 \\
\hline Wisconsin & 0 & 3595636 & 6114270 \\
\hline Wyoming & 0 & 0 & 487361 \\
\hline U.S. Total & 0 & 66127422 & 188067187 \\
\hline
\end{tabular}

\section{E. Urban Wood Wastes}

Urban wood wastes include yard trimmings, site clearing wastes, pallets, wood packaging, and other miscellaneous commercial and household wood wastes that are generally disposed of at municipal solid waste (MSW) landfills and demolition and construction wastes that are generally disposed of in construction/demolition (C/D) landfills. Data regarding quantities of these wood wastes is difficult to find and price information is even rarer. Additionally, definitions differ by states. Some states collect data on total wastes deposited at each MSW and C/D landfill in their states, and in some states, the quantities are further categorized by type (i.e., wood, paper and cardboard, plastics, etc.). However, not all states collect this data. Therefore, the quantities presented are crude estimates based on survey data (Glenn, 1998; Bush et al, 1997; Araman et al, 1997). 
For municipal solid wastes (MSW) a survey by Glenn, 1998 is used to estimate total MSW generated by state. These quantities are adjusted slightly to correspond to regional MSW quantities that are land-filled as estimated by a survey conducted by Araman et al, 1997. Using the Araman survey, the total amount of wood contained in land-filled MSW is estimated. According to this survey, about 6 percent of municipal solid waste in the Midwest is wood, with 8 percent of the MSW being wood in the South, 6.6 percent being wood in the Northeast and 7.3 percent being wood in the West. Estimated quantities were in wet tons; they were corrected to dry tons by assuming a 15 percent moisture content by weight.

To estimate construction and demolition wastes (C/D), the Glenn study and the Bush et al, 1997 survey were used. The Glenn study provided the number of $\mathrm{C} / \mathrm{D}$ landfills by state, and the Bush et al survey provided the average quantity of waste received per $\mathrm{C} / \mathrm{D}$ landfill by region as well as the regional percent of the waste that was wood. According to the Bush et al survey, C/D landfills in the Midwest receive an average 25,700 tons of waste per year with 46 percent of that quantity being wood. In the South, C/D landfills receive an average 36,500 tons of waste/yr with 39 percent being wood. Northeastern C/D landfills receive an average 13,700 tons of waste/yr with 21 percent being wood and Western C/D landfills receive an average 28,800 tons of waste/yr with 18 percent being wood. Estimated quantities were in wet tons; they were corrected to dry tons by assuming a 15 percent moisture content by weight.

Yard trimmings taken directly to a compost facility rather than land-filled, were estimated from the Glenn study. This estimate was made by multiplying the number of compost facilities in each state by the national average tons of material received by site ( 2750 tons). The total compost material was then corrected for the percent that is yard trimmings (assumed to be 80 percent) and for the quantity that is wood (assumed to be 90 percent). Quantities were corrected to dry tons by assuming a 40 percent moisture by weight.

In an effort to reduce the quantities of waste materials that are land-filled, most states actively encourage the recycling of wastes. Quantities and prices of recycled wood wastes are not readily available. However, the Araman and Bush surveys report limited data on the recycling of wood wastes at MSW and C/D sites. They report that in the South, approximately 36 percent of C/D landfills and 50 percent of MSW landfills operate a wood/yard waste recycling facility and that about 34 percent of the wood at C/D landfills and 39 percent of the wood at MSW landfills is recycled. In the Midwest, about 31 percent of the MSW and 25 percent of the C/D landfills operate wood recycling facilities with 16 percent of the MSW wood and 1 percent of the C/D wood is recycled. In the West, 27 percent of the MSW and C/D landfills operate wood recycling facilities and recycle 25 percent each of their wood. In the Northeast, 39 percent of the MSW and 28 percent of the C/D landfills operate wood recycling facilities and recycle 39 percent of the MSW wood and 28 percent of the C/D wastes.

The surveys do not report the use of total recycled wood, but do report the uses of recycled pallets which represent about 7 percent of the total wood and 4 percent of the recycled wood at C/D landfills and about 24 percent of the total wood and about 13 percent of the recycled wood at MSW landfills. At C/D landfills, about 14 percent of the recycled pallets are reused as pallets, about 39 percent are used as fuel, and the remainder is used for other purposes such as mulch and composting. About 69 percent of the recyclers reported that they gave away the pallet material. Of those selling the material, the mean sale price was $\$ 11.01 /$ ton and the median sale price was $\$ 10.50 /$ ton. At MSW landfills, about 3 percent of the recycled pallets are re-used as pallets, about 41 percent are used as fuel, and the remainder is used for other purposes such as mulch and composting. About 58 percent of the C/D recyclers reported that they gave away the pallet material. Of those selling the material, the mean sale price was $\$ 13.17 /$ ton and the median sale price was $\$ 10.67 /$ ton. Transportation costs must still be added to the sale price. Given the lack of information regarding prices, we assumed that of the total quantity available, 60 percent could be available at less than $\$ 20 /$ dry ton and that the remaining quantities could be available at less than $\$ 30$ /dry ton. Table 5 presents the estimated annual cumulative quantities of urban wood wastes by state and price.

\begin{tabular}{||l|l|l|l|l|}
\hline \multicolumn{2}{|c||}{$\begin{array}{l}\text { Table 5: Estimated Annual Cumulative Urban Wood Waste Quantities (dry tons), by } \\
\text { Delivered Price and State }\end{array}$} \\
\hline \multicolumn{1}{|c|}{} \\
\hline & $<\$ 20 /$ dry ton & $<\$ 30 /$ dry ton & $<\$ 40 /$ dry ton & $<\$ 50 /$ dry ton \\
\hline Alabama & 823566 & 1372610 & 1372610 & 1372610 \\
\hline \hline Arizona & 219736 & 366227 & 366227 & 366227 \\
\hline \hline Arkansas & 400364 & 667273 & 667273 & 667273 \\
\hline
\end{tabular}


- Bionass Feedstock Availability in the United States: 1999 State Level Analysis

\begin{tabular}{|c|c|c|c|c|}
\hline California & 1579813 & |2633022 & 2633022 & 2633022 \\
\hline Colorado & 94661 & 157769 & 157769 & 157769 \\
\hline Connecticut & 246938 & 411563 & 411563 & 411563 \\
\hline Delaware & 38959 & 64931 & 64931 & 64931 \\
\hline Florida & 2757950 & 4596584 & 4596584 & 4596584 \\
\hline Georgia & 862094 & 1436823 & 1436823 & 1436823 \\
\hline Idaho & 135265 & 338162 & 338162 & 338162 \\
\hline Illinois & 416047 & 693411 & 693411 & 693411 \\
\hline Indiana & 316610 & 527684 & 527684 & 527684 \\
\hline Iowa & 171802 & 286337 & 286337 & 286337 \\
\hline Kansas & 736289 & 1227148 & 1227148 & 1227148 \\
\hline Kentucky & 345699 & 576165 & 576165 & 576165 \\
\hline Louisiana & 452322 & 753870 & 753870 & 753870 \\
\hline Maine & 108358 & 180597 & 180597 & 180597 \\
\hline Maryland & 204643 & 341071 & 341071 & 341071 \\
\hline Massachusetts & 419272 & 698787 & 698787 & 698787 \\
\hline Michigan & 495734 & 826224 & 826224 & 826224 \\
\hline Minnesota & 919517 & 1532529 & 1532529 & 1532529 \\
\hline Mississippi & 470831 & 784719 & 784719 & 784719 \\
\hline Missouri & 315547 & 525911 & 525911 & 525911 \\
\hline Montana & 52060 & 86766 & 86766 & 86766 \\
\hline Nebraska & 102073 & 170121 & 170121 & 170121 \\
\hline Nevada & 184112 & 306853 & 306853 & 306853 \\
\hline New Hampshire & 110579 & 184298 & 184298 & 184298 \\
\hline New Jersey & 389089 & 648481 & 648481 & 648481 \\
\hline New Mexico & 142896 & 238160 & 238160 & 238160 \\
\hline New York & 1140080 & 1900133 & 1900133 & 1900133 \\
\hline North Carolina & 636035 & 1060056 & 1060056 & 1060056 \\
\hline North Dakota & 326510 & 544184 & 544184 & 544184 \\
\hline Ohio & 744518 & 1240864 & 1240864 & 1240864 \\
\hline Oklahoma & 111173 & 185289 & 185289 & 185289 \\
\hline Oregon & 182532 & 304220 & 304220 & 304220 \\
\hline Pennsylvania & 399963 & 666605 & 666605 & 666605 \\
\hline Rhode Island & 29803 & 49671 & 49671 & 49671 \\
\hline South Carolina & 1289900 & 2149833 & 2149833 & 2149833 \\
\hline South Dakota & 123982 & 206637 & 206637 & 206637 \\
\hline Tennessee & 676029 & 1126715 & 1126715 & 1126715 \\
\hline Texas & 1209449 & 2015749 & 2015749 & 2015749 \\
\hline Utah & 138765 & 231275 & 231275 & 231275 \\
\hline Vermont & 40802 & 68004 & 68004 & 68004 \\
\hline Virginia & 519454 & 865757 & 865757 & 865757 \\
\hline Washington & 292432 & 487387 & 487387 & 487387 \\
\hline
\end{tabular}


. Biomass Feedstock Availability in the United States: 1999 State Level Analysis

\begin{tabular}{|c|c|c|c|c|}
\hline West Virginia & 105236 & 175393 & 175393 & |175393 \\
\hline Wisconsin & 383466 & 639110 & 639110 & 639110 \\
\hline Wyoming & 177383 & 295638 & 295638 & 295638 \\
\hline U.S. Total & 22040338 & 36846616 & 36846616 & 36846616 \\
\hline
\end{tabular}

\section{Summary}

Table 6 summarizes the estimated total annual cumulative quantities of biomass resources available by state and delivered price. It is estimated that substantial quantities of biomass ( 510 million dry tons) could be available annually at prices of less that $\$ 50 / \mathrm{dt}$ delivered. However, several caveats should be noted. There is a great deal of uncertainty surrounding some of the estimates. For example, while there is substantial confidence in the estimated quantities of mill residues available by state, there is a great deal of uncertainty about the estimated prices of these residues. The value of these feedstocks in their current uses is speculative and based solely on anecdotal discussions. Given that the feedstock is already being used--much of it under contract or in-house by the generator of the waste--energy facilities may need to pay a higher price than assumed to obtain the feedstock. Additionally, both the quantity and price of urban wastes are highly speculative. The analysis is based solely on one national study and regional averages taken from two additional surveys. There is no indication of the quality of the material present (i.e., whether the wood is contaminated with chemicals, etc.). Because of the ways in which the surveys were conducted, there may be double counting of some quantities (i.e., MSW may contain yard trimmings and C/D wastes as well). Additionally, the analysis assumes that the majority of this urban wood is available for a minimal fee, with much of the cost resulting from transportation. Other industries have discovered that once a market is established, these "waste materials" become more valuable and are no longer available at minimal price. This situation could also happen with urban wastes used for energy if a steady customer becomes available. It should also be noted however, that some studies indicate that greater quantities of urban wastes are available, and are available at lower prices, than are assumed in this analysis (Wiltsee, 1998). Given the high level of uncertainty surrounding the quantity and price estimates of urban wastes and mill residues, and the fact that these wastes are estimated to be the least cost feedstocks available, they should be viewed with caution until a more detailed analysis is completed.

The analysis has assumed that substantial quantities of dead forest wood could be harvested. The harvest of deadwood is a particularly dangerous activity and not one relished by most foresters. Additionally, large polewood trees represent the growing stock of trees, that if left for sufficient time, could be harvested for higher value uses. These opportunity costs have not been considered. And, the sustainability of removing these forest resources has not been thoroughly analyzed.

We estimate the price of agricultural residues to be high largely because of the small quantities that can be sustainably removed on a per acre basis. Improvements in the collection/transport technologies and the ability to sustainably collect larger quantities (due to a shift in no-till site preparation practices for example) could increase quantities and decrease prices over time. Also, the inclusion of some of the minor grain crops (i.e., barley, oats, rye, rice) and soybeans could increase the total quantities of agricultural residues available by state. However, further elucidation of quantities that can sustainably be removed might lower available quantities.

Dedicated energy crops (i.e., switchgrass and short rotation wood crops) are not currently produced--the analysis is based on our best estimates of yield, production costs, and profitability of alternative crops that could be produced on the same land. Improving yields and decreasing production costs through improved harvest and transport technologies could increase available quantities at lower costs.

We have assumed a transportation cost of $\$ 8 /$ dry ton for most feedstocks. This cost is based on a typical cost of transporting materials (i.e., switchgrass bales and wood chips) for less than 50 miles (Graham et al, 1996; Bhat et al, 1992; Noon et al, 1996). Finally, the analysis is conducted at a state level and the distribution of biomass resources within the state is not specifically considered. We have simply assumed that the feedstock is available within 50 miles of a user facility. This may not be the case which would result either in the cost of the feedstock being higher to a user facility due to increased transportation costs, or the quantities of available feedstock being lower to a user facility if the material is simply too far away from the end-user site to be practical to obtain. Biomass resource assessments are needed at a lower aggregation level than the state. Any facility considering using the analysis need to conduct its own local analysis to 
- Biomass Feedstock Availability in the United States: 1999 State Level Analysis verify feedstock quantity and prices.

Table 6: Estimated Cumulative Biomass Quantities (dry ton/yr), by Delivered Price and State

\begin{tabular}{|c|c|c|c|c|}
\hline & $<\$ 20 /$ dry ton & $<\$ 30 /$ dry ton & $<\$ 40 /$ dry ton & $<\$ 50 /$ dry ton \\
\hline Alabama & 840566 & 6962610 & 10712357 & 17681689 \\
\hline Arizona & 219736 & 575227 & 863091 & 1100491 \\
\hline Arkansias & 402364 & 4092273 & 7085549 & 13604348 \\
\hline California & 1587813 & 6158022 & 8224305 & 11298705 \\
\hline Colorado & 180661 & 651769 & 3356589 & 3581889 \\
\hline Connecticut & 246938 & 560563 & 610563 & 906309 \\
\hline Delaware. & 38959 & 94931 & 194008 & 461521 \\
\hline Florida & 2761950 & 6753122 & 6778408 & 9533398 \\
\hline Georgia & 934094 & 6390823 & 8540684 & 16111675 \\
\hline Idaho & 204265 & 2572162 & 4117282 & 7165782 \\
\hline Illinois & 435047 & 1038411 & 26838517 & 33359162 \\
\hline Indiana & 347610 & 993684 & 13409571 & 18606863 \\
\hline lowa & 173802 & 404337 & 24582843 & 32786037 \\
\hline Kansas & 737289 & 1283148 & 12733412 & 21343522 \\
\hline Kentucky & 454699 & 1472165 & 5757811 & 10809048 \\
\hline Louisiana & 516322 & 3568870 & 7976754 & 11834427 \\
\hline Maine & 151358 & 1195597 & 1571597 & 2213697 \\
\hline Maryland & 204643 & $543071^{\circ}$ & 899539 & 1959222 \\
\hline Massachusetts & 419272 & 938787 & 1026787 & 1435895 \\
\hline Michigan & 505734 & 2468224 & 4627235 & 12163103 \\
\hline Minnesota & 990517 & 2916529 & 15493892 & 21247327 \\
\hline Mississippi & 598831 & 4908719 & 10673390 & 17930978 \\
\hline Missouri & 477547 & 1345911 & 8029706 & 19522892 \\
\hline Montana & 69060 & 1421766 & 2159358 & 6761444 \\
\hline Nebraska & 114073 & 210121 & 18467094 & 21773296 \\
\hline Nevada & 184112 & 314853 & 333203 & 336603 \\
\hline New Hampshire & 133579 & 922298 & 1061298 & 2016455 \\
\hline New Jersey & 389089 & 726481 & 791204 & 975806 \\
\hline New Mexico & 167896 & 424160 & 960689 & 1081589 \\
\hline New York & 1168080 & 3328133 & 3884648 & 8438083 \\
\hline
\end{tabular}


. Biomass Feedstock Availability in the United States: 1999 State Level Analysis

\begin{tabular}{|c|c|c|c|c|}
\hline North Carolina & 669035 & 4188056 & $\| 5789513$ & 10855777 \\
\hline North Dakota & 326510 & 558184 & 2506662 & 21043177 \\
\hline Ohio & 744518 & 1472864 & 13018429 & 18962520 \\
\hline Oklahoma & 111173 & 3873692 & 7816207 & 12699956 \\
\hline Oregon & 192532 & 3341220 & 4126075 & 9809975 \\
\hline Pennsylvania & 571963 & 2205605 & 2832294 & 7427043 \\
\hline Rhode Island & 29803 & 80671 & 87671 & 115514 \\
\hline South Carolina & 1293900 & 4468833 & 6332258 & 9368065 \\
\hline South Dakota & 131982 & 285637 & 9601746 & 16005411 \\
\hline Tennessee & 878029 & 3381715 & 10720281 & 15232952 \\
\hline Texas & 1227449 & 4221749 & 13526432 & 20747118 \\
\hline Utah & 158765 & 388275 & 647821 & 722821 \\
\hline Vermont & 40802 & 392004 & 513004 & 1022669 \\
\hline Virginia & 599454 & 3058757 & 5055411 & 8714941 \\
\hline Washington & 297432 & 3979387 & 5938641 & 9920241 \\
\hline West Virginia & 241236 & 1361393 & 1971651 & 3736487 \\
\hline Wisconsin & 425466 & 2450110 & 11502364 & 14963398 \\
\hline Wyoming & 224383 & 551638 & 787223 & 1465684 \\
\hline U.S. Total & 23820338 & 105496557 & 314535067 & 510855005 \\
\hline
\end{tabular}

\section{REFERENCES}

1. American Society of Agricultural Engineers, Standards 1995-Standards, Engineering Practices, and Data, 1995.

2. P.A. Araman, R.J. Bush, and V.S. Reddy, Municipal Solid Waste Landfills and Wood Pallets--What's Happening in the U.S., Pallet Enterprise, March 1997, pp. 50-56.

3. M.B. Bhat, B.C. English, and M. Ojo, Regional Costs of Transporting Biomass Feedstocks, Liquid Fuels From Renewable Resources, John S. Cundiff (ed.), American Society of Agricultural Engineers, St. Joseph, MI, December 1992.

4. R.J. Bush, V.S. Reddy, and P.A. Araman, Construction and Demolition Landfills and Wood Pallets--What's Happening in the U.S., Pallet Enterprise, March 1997, pp. 27-31.

5. D.G. de la Torre Ugarte, S.P. Slinsky, and D.E. Ray, The Economic Impacts of Biomass Crop Production on the U.S. Agriculture Sector, University of Tennessee Agricultural Policy Analysis Center, Knoxville, TN, July 1999, Draft Document.

6. Doane's Agricultural Report, Estimated Machinery Operating Costs, 1995, Vol..58, No. 15-5, April 14, 1995.

7. J. Glenn, The State of Garbage, BioCycle, April 1998, pp.32-43.

8. R. Gogerty, Crop Leftovers: More Uses, More Value, Resource: Engineering and Technology for a Sustainable World, Vol. 3, No. 7, July 1996.

9. R.L. Graham, W. Liu, H.I. Jager, B.C. English, C.E. Noon, and M.J. Daly, A Regional-Scale GIS-Based Modeling System for Evaluating the Potential Costs and Supplies of Biomass From Biomass Crops, in Proceedings of Bioenergy '96 - The Seventh National Bioenergy Conference, Nashville, TN, September 15-20, 1996, Southeastern Regional Biomass Energy Program, pp. 444-450, 1996.

10. W.G. Heid, Jr., Turning Great Plains Crop Residues and Other Products into Energy, U.S. Department of 
. Biomass Feedstock Availability in the United States: 1999 State Level Analysis

Agriculture, Economic Research Service, Agricultural Economic Report No. 523, Washington, DC, November 1984.

11. D.T. Lightle, A Soil Conditioning Index for Cropland Management Systems (Draft), U.S. Department of Agriculture, Natural Resources Conservation Service, National Soil Survey Center, April 1997.

12. A. McQuillan, K. Skog, T. Nagle, and R. Loveless, Marginal Cost Supply Curves for Utilizing Forest Waste Wood in the United States, Unpublished Manuscript, University of Montana, Missoula, February 1984.

13. NEOS Corporation, Non-synthetic Cellulosic Textile Feedstock Resource Assessment, Southeastern Regional Biomass Energy Program, Muscle Shoals, AL, July 1998.

14. C.E. Noon, M.J. Daly, R.L. Graham, and F.B. Zahn, Transportation and Site Location Analysis for Regional Integrated Biomass Assessment (RIBA), in Proceedings of Bioenergy '96 - The Seventh National Bioenergy Conference, Nashville, TN, September 15-20, 1996, Southeastern Regional Biomass Energy Program, pp. 487-493, 1996.

15. North American Dealers Association, Official Guide--Tractors and Farm Equipment, 1995.

16. T. Schechinger, Great Lakes Chemical Corporation, personal communication, 1997.

17. U.S. Department of Agricultural, National Agricultural Statistics Service, World Agricultural Outlook Board, USDA Agricultural Baseline Projections to 2009, WAOB-99-1, Washington, DC, February 1999.

18. U.S. Department of Agriculture, Forest Service, Forest Inventory and Analysis Timber Product Output Database Retrieval System, (http://srsfia.usfs.msstate.edu/rpa/tpo), 1998a.

19. U.S. Department of Agriculture, National Agricultural Statistical Service, Crop Production Summary, Washington, DC, January 1998 b.

20. U.S. Department of Agriculture, Economic Research Service, Agricultural Resources and Environmental Indicators, 1996-1997, Agricultural Handbook No. 712, Washington, DC, July 1997.

21. U.S. Department of Agriculture, Economic Research Service, Economic Indicators of the Farm Sector: Costs of Production--Major Field Crops, 1995, Washington, DC, 1996.

22. M.E. Walsh, R.L. Perlack, D.A. Becker, A. Turhollow, and R.L. Graham, Evolution of the Fuel Ethanol Industry: Feedstock Availability and Price, Oak Ridge National Laboratory, Oak Ridge, TN, April 21, 1998, Draft Document.

23. G. Wiltsee, Urban Wood Waste Resources in 30 US Metropolitan Areas, Appel Consultants, Inc., Valencia, CA, 1998.

1. Logging residues are the unused portion of the growing of stock trees (i.e., commercial species with a diameter breast height (dbh) greater than 5 inches, excluding cull trees) that are cut or killed by logging and left behind. Rough trees are those that do not contain a sawlog (i.e., 50 percent or more of live cull volume) or are not a currently merchantable species. Rotten trees are trees that do not contain a sawlog because of rot (i.e., 50 percent or more of the live cull volume). Salvable dead wood includes downed or standing trees that are considered currently or potentially merchantable. Excess saplings are live trees having a dbh of between 1.0 and 4.9 inches. Small pole trees are trees with a dbh greater than 5 inches, but smaller than saw timber trees. (back to report)

2. Retrieval efficiency accounts for the quantity of the inventory that can actually be recovered due to technology or equipment (assumed to be 40 percent). It is assumed that 50 percent of the resource is accessible without having to construct roads, except for logging residues for which 100 percent of the inventory is assumed accessible. Finally, inventory that lies on slopes greater than 20 percent or where conventional equipment cannot be used are eliminated for cost and environmental reasons. (back to report)

3. The assumed residue factors are-- 1 ton of corn stover for every $I$ ton of corn grain produced; 1.7 tons of wheat straw for every 1 ton of winter wheat grain; and 1.3 ton of wheat straw for every 1 ton of spring and duram wheat grain (Heid, 1984). We assume a grain weight of 56 and $60 \mathrm{lb} / \mathrm{bu}$ for corn and wheat grain respectively. Grain moisture factors are assumed to be 1 for corn and .87 for wheat. (back to report) 